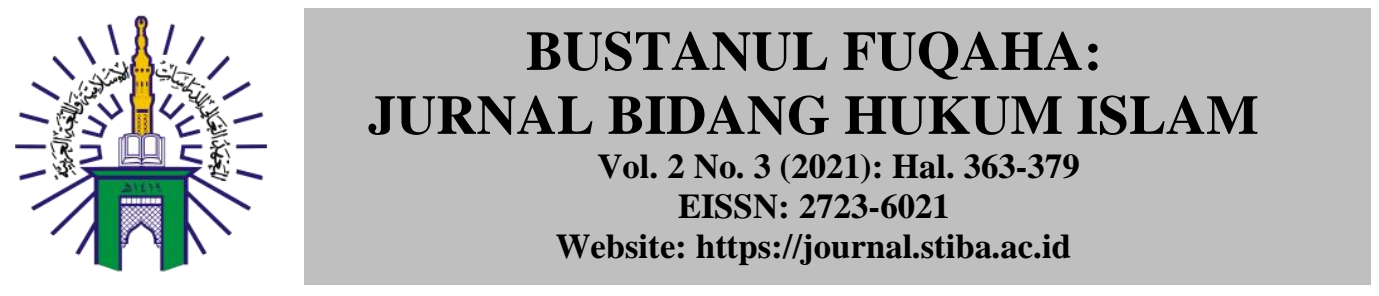

\title{
PEMBAGIAN HARTA WARISAN SEBELUM PEWARIS MENINGGAL DUNIA DALAM TINJAUAN HUKUM ISLAM (STUDI KASUS DI DESA GENTUNGAN KECAMATAN BAJENG BARAT KABUPATEN GOWA
}

\section{DISTRIBUTION OF INHERITANCE BEFORE HEIR DIED IN ISLAMIC LAW VIEW (CASE STUDY IN GENTUNGAN VILLAGE, BAJENG BARAT DISTRICT, GOWA REGENCY)}

\section{Hendra Wijaya}

Sekolah Tinggi Ilmu Islam dan Bahasa Arab (STIBA) Makassar

Email: abumuslimhwj@gmail.com

\section{Sa'adal Jannah}

Sekolah Tinggi Ilmu Islam dan Bahasa Arab (STIBA) Makassar

Email: saadaljannah@stiba.ac.id

\section{Farida Aprianti}

Sekolah Tinggi Ilmu Islam dan Bahasa Arab (STIBA) Makassar

Email: farida_aprianti@stiba.ac.id

\section{Hasmira}

Sekolah Tinggi Ilmu Islam dan Bahasa Arab (STIBA) Makassar

Email: hasmirahasyim@gmail.com

\begin{tabular}{|c|c|}
\hline Keywords : & ABSTRACT \\
\hline Heir, Inheritance, Islamic Law & $\begin{array}{l}\text { This study examines the distribution on inheritance before the heir dies } \\
\text { in the Gantungan community. The perpose of this research is to find out; } \\
\text { implementation of the distribution on inheritance before the heir dies, as } \\
\text { well as the distribution of inheritance before the heir dies in a review of } \\
\text { Islamic law. This research uses qualitative research throught normative } \\
\text { theological approach and inductive approach. The results show that the } \\
\text { implications of the distribution of inheritance process by giving } \\
\text { inheritance to the heirs before the oewner of the property dies, but some } \\
\text { of them divide the inheritance after the heir dies. People in general do } \\
\text { not understand the timing of the distribution of inheritance, the type of } \\
\text { inherited property and the process of dividing the inheritance. As for } \\
\text { when viewed from Islamic law, then this a grant because in Islamic law } \\
\text { inheritance occurs because of the principle of death. }\end{array}$ \\
\hline \multirow{2}{*}{$\begin{array}{l}\text { Kata kunci : } \\
\text { Ahli Waris, Harta Warisan, } \\
\text { Hukum Islam }\end{array}$} & ABSTRAK \\
\hline & $\begin{array}{l}\text { Penelitian ini menelaah pembagian warisan sebelum pewaris meninggal } \\
\text { dunia pada masyarakat Gentungan. Tujuan penelitian ini untuk } \\
\text { mengetahui; Implementasi pembagian harta warisan sebelum pewaris } \\
\text { meninggal dunia, serta pembagian harta warisan sebelum pewaris } \\
\text { meninggal dunia dalam tinjauan hukum Islam. Penelitian ini } \\
\text { menggunakan jenis penelitian kualitatif melalui pendekatan teologi } \\
\text { normatif dan pendekatan induktif. Hasil penelitian menunjukkan bahwa } \\
\text { implikasi pembagian harta warisan pada masyarakat Gentungan pada } \\
\text { umumnya melakukan proses pewarisan dengan cara memberikan harta }\end{array}$ \\
\hline
\end{tabular}


Diterima: 2 September 2021; Direvisi: 21 September 2021; Disetujui: 7 Oktober 2021; Tersedia online: 3 Desember 2021

How to cite: Hendra Wijaya, Sa'adal Jannah, Farida Aprianti, Hasmira, "Pembagian Harta Warisan Sebelum Pewaris Meninggal Dunia dalam Tinjauan Hukum Islam (Studi Kasus di Desa Gentungan Kecamatan Bajeng Barat Kabupaten Gowa", BUSTANUL FUQAHA: Jurnal Bidang Hukum Islam Vol. 2, No. 3 (2021): 363-379. doi: 10.36701/bustanul.v2i3.403.

\section{PENDAHULUAN}

Manusia sebagai makhluk ciptaan Allah swt. yang telah dikodratkan sebagai khalifah di atas muka bumi, di mana Allah swt. telah menyatakan di depan para malaikat tentang ide penciptaan manusia. Malaikat pun menanggapi dengan kekhawatiran bahwa manusia hanya akan berbuat kerusakan dan pertumpahan darah di atas muka bumi. Namun, Allah swt. tentunya telah menetapkan seperangkat sistem pengaturan untuk mengatur kehidupan manusia di atas muka bumi. Hal tersebut tidak lain untuk mengantisipasi dan memperkecil kemungkinan terjadinya ihwal apa yang dirisaukan oleh para malaikat. Semua aturan itu sejatinya bertujuan untuk kebaikan manusia itu sendiri. Adapun aturan Allah swt. tentang tingkah laku manusia secara sederhana disebut syari'ah atau hukum syara' yang saat ini disebut dengan hukum Islam.

Hukum Islam merupakan hukum Allah swt. dan sebagai hukum Allah swt., ia menuntut kepatuhan dari umat Islam untuk melaksanakannya sebagai kelanjutan dari keimanannya kepada Allah swt. Hukum Islam sendiri meliputi seluruh segi kehidupan manusia di dunia dan akhirat kelak. Di antara hukum tersebut ada yang mengandung sanksi baik di dunia maupun di akhirat. Sebahagian yang lain justru tidak mengandung sanksi, yang ada hanya tuntutan untuk patuh.

Dari segi kehidupan manusia yang diatur oleh Allah swt. dapat dikelompokkan menjadi dua kelompok. Pertama, hal-hal yang berkaitan dengan hubungan lahir manusia dengan Allah swt. Aturan tentang hal ini disebut hukm 'ibādāt. Tujuannya untuk menjaga hubungan atau tali antara Allah swt. dengan hamba-Nya yang disebut juga hamblu min Allāh. Kedua, berkaitan dengan hubungan antar manusia dan alam sekitarnya. Aturan tentang hal ini disebut hukm al-mu'āmalāt. Tujuannya menjaga hubungan antara manusia dan alamnya atau yang disebut hablun min al nās ${ }^{1}$. Kedua hubungan itu harus tetap terpelihara agar manusia terlepas dari kehinaan, kemiskinan dan kemarahan Allah swt. yang dinyatakan dalam Qs. Ali Imran/3:112,

\footnotetext{
${ }^{1}$ Amir Syarifuddin, Hukum Kewarisan Islam (Cet. I; Jakarta: Prenada Media, 2004), h. 3.
} 


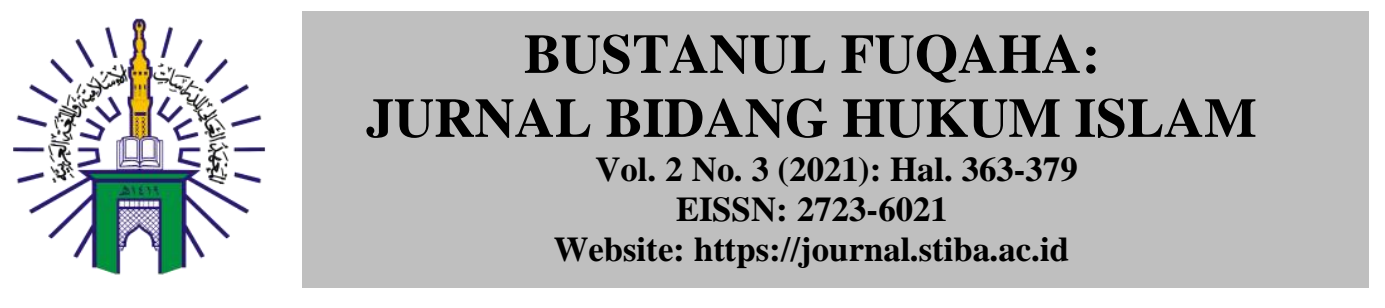

\section{BUSTANUL FUQAHA}

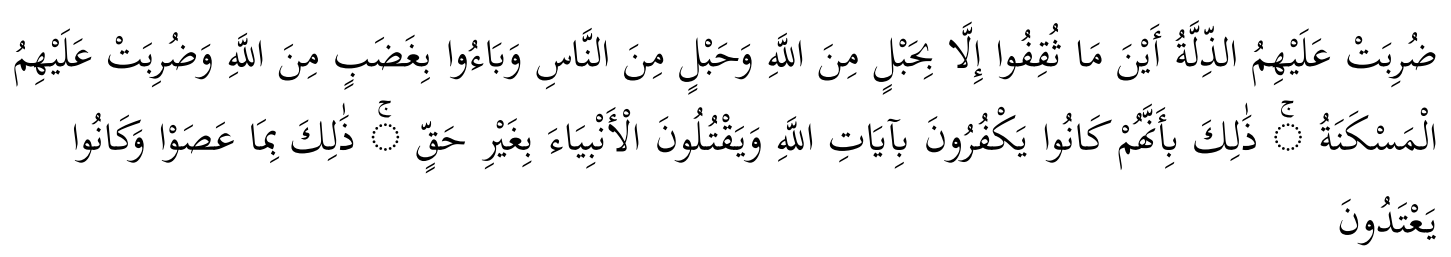

Terjemahnya:

Mereka diliputi kehinaan di mana saja mereka berada, kecuali jika mereka (berpegang) pada tali (agama) Allah swt. dan tali (perjanjian) dengan manusia. Mereka mendapat murka dari Allah swt. dan (selalu) diliputi kesengsaraan. Yang demikian itu karena mereka mengingkari ayat-ayat Allah swt. dan membunuh para nabi, tanpa hak (alasan) yang benar. Yang demikian itu karena mereka durhaka dan melampaui batas².

Di antara aturan yang mengatur hubungan antara manusia yaitu harta warisan. Harta warisan merupakan harta dan kepemilikan yang timbul dari akibat suatu kematian. Aturan tentang warisan tersebut disebutkan jelas dan terperinci di dalam al-Qur'an dan hadis Rasulullah saw.

Hukum waris sebelum Islam sangat dipengaruhi oleh sistem sosial yang dianut oleh masyarakat yang ada. Masyarakat jahiliah, dengan pola masyarakatnya yang bercorak kesukuan (tribalisme), memiliki kebiasaan berpindah-pindah (nomaden), suka berperang dan merampas jarahan. Sebagian lagi dari mereka bermata pencaharian sebagai pedagang. Ciri-ciri tersebut tampaknya sudah menjadi kultur atau budaya yang mapan. Oleh karena itu, budaya tersebut ikut membentuk nilai-nilai, sistem hukum dan sistem sosial yang berlaku. Kekuatan fisik lalu menjadi ukuran baku di dalam sistem hukum warisan yang diberlakukan ${ }^{3}$. Akan tetapi, sejak kedatangan ajaran Islam, aturan warisan menjamin hak seluruh ahli waris, menjaga kehormatan dan mewujudkan keadilan dalam masyarakat. Di antara sebab beralihnya harta seseorang yang telah mati kepada yang masih hidup adalah adanya hubungan pernikahan dan kekerabatan antara keduanya ${ }^{4}$. Adanya hubungan kekerabatan ditentukan oleh adanya hubungan darah yang ditentukan pada saat adanya kelahiran ${ }^{5}$.

Hukum waris di Indonesia merupakan satu hukum perdata secara keseluruhan dan merupakan sebagian kecil dari hukum kekeluargaan. Hukum waris terkait erat dengan ruang lingkup kehidupan manusia, karena setiap manusia pasti akan mengalami peristiwa hukum yaitu adanya kematian, sehingga akan menimbulkan akibat hukum dari peristiwa kematian seseorang, di antaranya adalah masalah bagaimana kelanjutan hak-hak dan kewajiban-kewajiban seseorang yang meninggal dunia. Bagaimana penyelesaian hak dan

\footnotetext{
${ }^{2}$ Kementerian Agama Republik Indonesia, al-Qur'an dan Terjemahnya (Cet. I; Jakarta: Sahifa, 2014), h. 64.

${ }^{3}$ Ahmad Rofiq, Fiqh Mawaris (Cet. IV; Jakarta: RajaGrafindo Persada, 2002), h. 8.

${ }^{4}$ Shālih bin Fauzān bin Abdullah al-Fauzān, Al-Tahqīqātu al-Marḍiyyah fì al-Mabāhis alFarḍiyyah (Cet. IV; Riyaḍ: Maktabah Ma'ārif, 1419 H/1999 M), h. 38.

${ }^{5}$ Amir Syarifuddin, Hukum Kewarisan Islam, h. 175.
} 
kewajiban sebagai akibat meninggalnya seseorang tersebut diatur oleh hukum waris ${ }^{6}$. Bagi umat Islam Indonesia, aturan Allah swt. tentang kewarisan telah menjadi hukum positif yang dipergunakan dalam Pengadilan Agama dalam memutuskan kasus pembagian maupun persengketaan berkenaan dengan harta waris tersebut ${ }^{7}$.

Dalam Islam hukum kewarisan mendapatkan perhatian besar, hal ini dikarenakan pembagian warisan seringkali menimbulkan akibat-akibat yang tidak menguntungkan atau bahkan mendatangkan perselisihan bagi para ahli waris. Ketidakpuasan akan harta benda sudah menjadi naluri manusia untuk mempunyai sebanyak mungkin sehingga memotivasi seseorang untuk menghalalkan berbagai macam cara untuk menguasainya, termasuk di dalamnya yaitu harta peninggalan pewarisnya sendiri. Realitas ini telah ada dalam sejarah umat manusia hingga sekarang, hal ini dibuktikan dengan terjadinya kasuskasus gugat waris yang diajukan ke pengadilan, baik di pengadilan agama maupun pengadilan negeri ${ }^{8}$.

Pemberian harta warisan pada umumnya diberikan sesudah pewaris meninggal. Namun, pemberian harta warisan sebelum pewaris meninggal dunia (semasa hidup) adalah hal yang tidak biasa dalam hukum waris. Pewaris membagikan sebahagian hartanya atau barang-barang kepada ahli waris sebelum pewaris meninggal sebagai langkah awal permulaan pewarisan. Realitas ini terjadi pada proses pembagian harta warisan masyarakat Gentungang, Kecamatan Bajeng Barat, Kabupaten Gowa di mana pembagian warisan mulai diberlakukan ketika seorang anak sudah dewasa atau sudah menikah. Hal ini dilakukan karena pada prinsipnya cara itu merupakan cara perdamaian yang pembagiannya dilakukan sebelum pewaris meninggal. Sehingga, nantinya tidak ada lagi pembagian warisan setelah pewaris meninggal.

Setiap anak mendapatkan warisan yang sama, tanpa harus melihat sistem kewarisan dalam Islam, yang pembagiannya sudah jelas di dalam al-Qur'an dan al-Hadis. Di antara permasalahan yang biasa muncul adalah ahli waris menjual harta warisan sebelum pewarisnya meninggal dunia dengan alasan kebutuhan ekonomi ${ }^{9}$. Keadaan ini membuat pewaris tidak rida warisannya dijual sebelum meninggal dunia.

Berkenaan dengan fenomena dan uraian narasi di atas, maka pokok permasalahan dalam penelitian ini adalah, "Pembagian Harta Warisan Sebelum Pewaris Meninggal Dunia Dalam Tinjauan Hukum Islam (Studi Kasus Desa Gentungang, Kecamatan Bajeng Barat, Kabupaten Gowa). Dari pokok permasalahan tersebut, penulis merumuskan beberapa sub masalah yang akan dijadikan acuan dan dikembangkan dalam pengkajiannya, antara lain sebagai berikut: 1) Bagaimana pembagian warisan dalam perspektif hukum Islam?; 2) Bagaimana implementasi pembagian harta warisan sebelum pewaris meninggal dunia di Desa Gentungang dan pandangan syariat terhadapnya?. Dengan demikian, tujuan penelitian ini tidak lain: 1) Untuk mengetahui pembagian harta warisan sebelum pewaris meninggal dunia di Desa Gentungan, kecamatan Bajeng Barat, 2018), h.1.

${ }^{6}$ Ellyne Dwi Poespasari, Hukum Waris Adat Di Indonesia (Cet. I; Jakarta: Prenada Media Group,

${ }^{7}$ Amir Syarifuddin, Hukum Kewarisan Islam, h. 4.

${ }^{8}$ Ahmad Rofiq, Hukum Islam di Indonesia h. 355.

${ }^{9}$ Rukiah dan Herman, "Penyelesaian Sengketa dalam Kewarisan Adat dalam Perpsektif Hukum Islam” Junrnal Hukum Diktum IX, no 2. (Juli 2011), h. 21. 


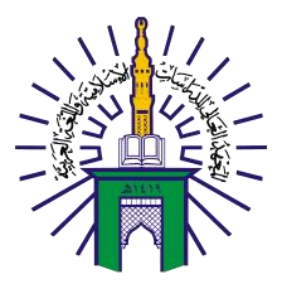

\section{BUSTANUL FUQAHA: \\ JURNAL BIDANG HUKUM ISLAM \\ Vol. 2 No. 3 (2021): Hal. 363-379 \\ EISSN: 2723-6021 \\ Website: https://journal.stiba.ac.id}

Kabupaten Gowa; dan 2) Untuk mengetahui tinjauan hukum Islam terhadap proses pembagian harta warisan sebelum pewaris meninggal yang dilaksanakan di tempat tersebut.

Metode penelitian yang digunakan dalam penelitian ini adalah penelitian kualitatif dengan pendekatan teologi normatif dan pendekatan induktif. Adapun untuk menunjang kebaruan pada penelitian ini, maka perlu untuk dicantumkan penelitian terdahulu yang berkaitan dengannya, di antaranya;

1) Penelitian yang berjudul, "Pembagian Harta Sebelum Orang Tua Meninggal Dunia pada Masyarakat Adat Bulukumba Ditinjau dari Hukum Islam (Studi Kasus di Kelurahan Caile Kecamatan Ujung Bulu Kabupaten Bulukumba)". Hasil penelitian ditemukan bahwa alasan orang tua semasa hidupnya mengalihkan hartanya kepada anak-anaknya karena merupakan bentuk kasih sayang orang tua dan merupakan bekal untuk kehidupan anak-anaknya di masa depan. Adapun status kepemilikan harta yang diberikan pewaris semasa hidupnya sudah menjadi milik mutlak ahli waris dan tidak dapat dikembalikan lagi kepada pewaris ${ }^{10}$.

2) Penelitian yang berjudul, "Pembagian Harta Warisan; Telaah Pembagian Warisan Oleh Pewaris kepada Ahli Waris Sebelum Pewaris Meninggal pada Masyarakat Bima". Hasil penelitian mengungkap bahwa pembagian warisan oleh pewaris kepada ahli waris sebelum pewaris meninggal dapat dilihat dari dua segi yaitu ditinjau dari hukum Islam bahwa cara tersebut dinamakan hibah, namun sebagian masyarakat Bima menamakan sebagai harta warisan. Sehingga, terdapat ketidaksesuaian antara adat dengan hukum kewarisan Islam. Sementara ditinjau dari aspek kemaslahatan terhadap praktik pembagian warisan oleh pewaris kepada ahli waris sebelum pewaris meninggal dunia diharapkan anak sebagai ahli waris yang menerima harta tersebut bisa membangun ekonomi sendiri dan mengelola dengan mandiri terhadap harta yang dibagikan pewaris tanpa menunggu pewaris meninggal dunia serta untuk menghindari konflik dalam keluarga ${ }^{11}$.

3) Penelitian yang berjudul, "Sistem Pelaksanaan Pembagian Harta Warisan Pada Masyarakat Islam di Desa Parappe Kecamatan Campalagian Kabupaten Polewali Mandar Sulawesi Barat." Hasil pengkajiannya mengemukakan bahwa pembagian warisan di Desa Parappe Kecamatan Campalagian dilakukan setelah orang tua (pewaris) wafat, namun ada juga masyarakat mau memberikan sebagian hartanya kepada anaknya yang telah dinikahkannya (menikah), kondisi ini termasuk ke dalam pengkategorian hibah, namun tetap pada dasarnya masyarakat setempat menganggapnya sebagai pembagian warisan ${ }^{12}$.

${ }^{10}$ Nurjannah, "Pembagian Harta Sebelum Orang Tua Meninggal Dunia pada Masyarakat Adat Bulukumba Ditinjau dari Hukum Islam (Studi Kasus di Kelurahan Caile Kecamatan Ujung Bulu Kabupaten Bulukumba" Skripsi, Universitas Negeri Alauddin Makassar, 2012.

${ }^{11}$ Jainuddin, "Pembagian Harta Warisan; Telaah Pembagian Warisan Oleh Pewaris kepada Ahli Waris sebelum Pewaris Meninggal pada Masyarakat Bima” Sangaji Jurnal Pemikiran Syariah dan Hukum, IV, no. 2, (Maret, 2020).

${ }^{12}$ Megawati, Megawati. Sistem Pelaksanaan Pembagian Harta Warisan pada Masyarakat Islam Desa Parappe, Kecamatan Campalagian, Kabupaten Polewali Mandar, Sulawesi Barat. Diss. Universitas Islam Negeri Alauddin, 2016. 
Berdasarkan studi pendahuluan di atas, tampak bahwa secara umum masyarakat menilai bahwa pembagian warisan sebelum pewaris meninggal dunia masih dianggap sebagai suatu warisan, padahal dalam tinjauan Islam masih perlu ditelusuri secara cermat melalui pengkajian terhadap nas-nas dan pendapat para ulama. Dengan demikian, penelitian ini berusaha mengkaji praktik pembagian warisan yang terjadi pada masyarakat di Desa Gentungang Kecamatan Bajeng Barat Kabupaten Gowa.

\section{PEMBAHASAN}

\section{Konsep Dasar Hukum Kewarisan Islam}

Hukum kewarisan Islam mengatur peralihan harta dari seseorang yang telah meninggal kepada yang masih hidup. Dalam literatur hukum Islam, hukum kewarisan Islam disebut dengan berbagai nama seperti: Farāid, Fiqh al-Mawārīṣ dan Hukm al-Wāris. Kata yang lazim dipakai adalah Farāid. Adapun literatur hukum di Indonesia, digunakan pula beberapa istilah seperti waris, warisan, pusaka dan hukum kewarisan. Dalam istilah hukum yang baku digunakan kata kewarisan, dengan mengambil kata asal 'waris' dengan tambahan awal 'ke' dan akhiran 'an'. Kata waris dapat berarti orang yang berhak menerima harta pusaka dari orang yang telah meninggal ${ }^{13}$. Makna lain dari kata waris adalah peralihan harta dari yang mati kepada yang masih hidup, yang berarti berfokus pada prosesnya. Arti yang terakhir ini yang digunakan dalam istilah hukum ${ }^{14}$.

Penggunaan kata 'hukum' diawalnya mengandung arti seperangkat aturan yang mengikat dan penggunaan kata 'Islam' di belakang mengandung arti 'dasar yang menjadi rujukan. Dengan demikian, definisi Hukum Kewarisan Islam yaitu peraturan tertulis berdasarkan al-Qur'an dan hadis tentang peralihan harta atau berupa barang dari yang telah mati kepada yang masih hidup, yang diakui dan diyakini berlaku dan mengikat untuk semua yang beragama Islam ${ }^{15}$. Adapun definisi hukum kewarisan Islam yang tertuang dalam Kompilasi Hukum Islam disebutkan bahwa hukum kewarisan adalah hukum yang mengatur tentang pemindahan hak pemilikan harta peninggalan (tarikah) pewaris, menentukan siapa-siapa yang berhak menjadi ahli waris dan berapa bagiannya masing-masing ${ }^{16}$.

\section{Sumber Hukum Kewarisan Islam}

\section{1) Al-Qur'an}

Ayat-ayat yang berkaitan dengan masalah kewarisan baik secara langsung maupun tidak langsung di dalam al-Qur'an dapat dijumpai dalam beberapa surat dan ayat, yaitu sebagai berikut:

a) Menyangkut tanggung jawab orang tua dan anak ditemui dalam Qs. AlBaqarah/2:233,

\footnotetext{
${ }^{13}$ https://kbbi.kemdikbud.go.id/entri/waris, diakses tanggal 30 September 2021

${ }^{14}$ Amir Syarifuddin, Hukum Kewarisan Islam, h. 5-6.

${ }^{15}$ Amir Syarifuddin, Hukum Kewarisan Islam, h. 6.

${ }^{16}$ Tim Redaksi Nuansa Aulia, Kompilasin Hukum Islam, h. 50.
} 


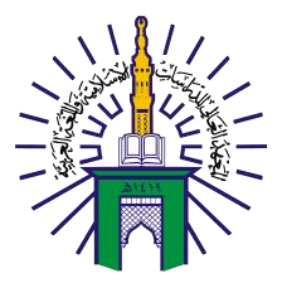

\section{BUSTANUL FUQAHA: \\ JURNAL BIDANG HUKUM ISLAM \\ Vol. 2 No. 3 (2021): Hal. 363-379 \\ EISSN: 2723-6021 \\ Website: https://journal.stiba.ac.id}

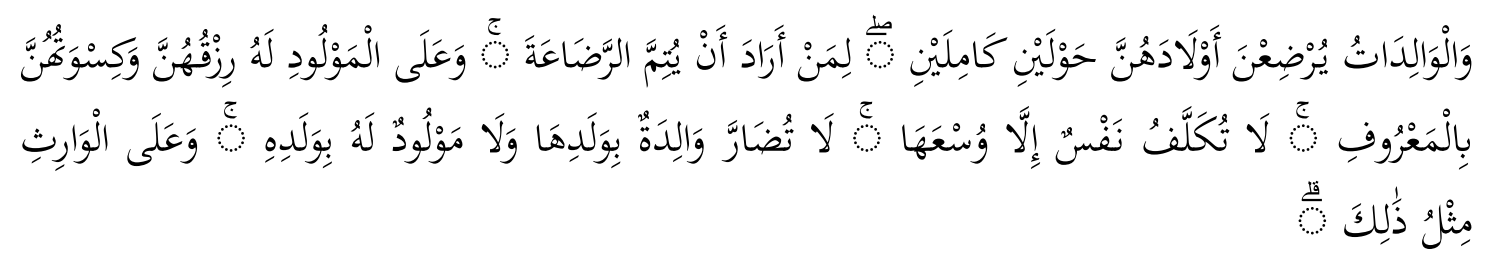

Terjemahnya:

Dan ibu-ibu hendaklah menyusui anak-anaknya selama dua tahun penuh, yaitu bagi yang ingin menyusui secara sempurna. Dan kewajiban ayah menanggung nafkah dan pakaian kepada para ibu dengan cara yang patut. Seseorang tidak dibebani lebih dari kesanggupannya. Janganlah seorang ibu menderita karena anaknya dan seorang ayah (menderita) karena anaknya, dan warispun (berkewajiban) seperti itu pula... ${ }^{17}$

Ayat ini menyatakan bahwa diwajibkan kepada seorang ayah memberi biaya hidup kepada ibu bayi, memberi hak-haknya, dan tidak memudaratkannya. Begitupun dengan anak sebagai ahli waris memberikan hak-hak terhadap orang tuanya ${ }^{18}$.

b) Menyangkut harta warisan dan pewarisnya ditemui dalam Qs. An-Nisa/4:33,

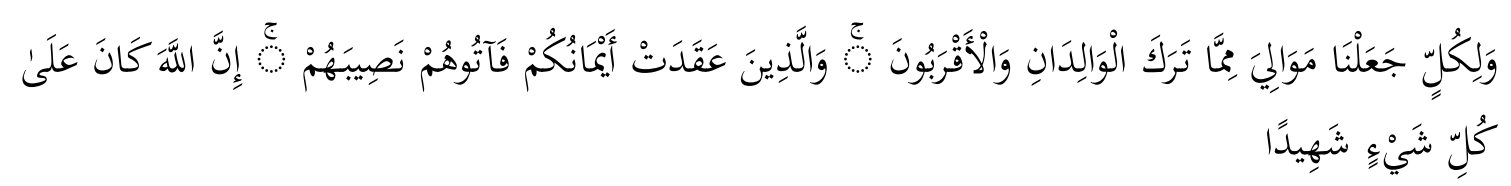

Terjemahnya:

Bagi tiap-tiap harta peninggalan dari harta yang ditinggalkan ibu bapak dan karib kerabat, Kami jadikan pewaris-pewarisnya. Dan (jika ada) orang-orang yang kamu telah bersumpah setia dengan mereka, maka berilah kepada mereka bahagiannya. Sesungguhnya Allah swt. menyaksikan segala sesuatu ${ }^{19}$.

c) Ayat yang memberi penjelasan tambahan mengenai kewarisan (berisi pengertian pembantu), misalnya yang berkaitan dengan $\hat{z} u l$ al-arhām (yang mempunyai hubungan atau pertalian darah) dalam Qs. An-Nisā/4:1,

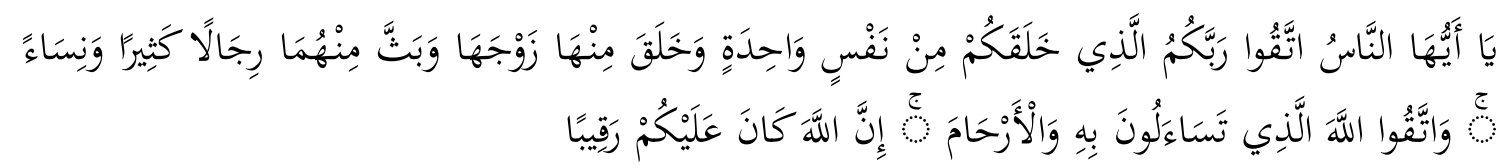

Terjemahnya:

Hai sekalian manusia, bertakwalah kepada Tuhan-mu yang telah menciptakan kamu dari seorang diri, dan dari padanya Allah swt. menciptakan isterinya; dan dari

\footnotetext{
${ }^{17}$ Kementerian Agama Republik Indonesia, al-Qur'an dan Terjemahnya, h. 37.

${ }^{18}$ Ismā'il bin Khatīb Abī Hafsh 'Umar bin Kas̀īr, Tafsīru al-Qur'an al- 'Ażìm, Juz I, h. 249.

${ }^{19}$ Kementerian Agama Republik Indonesia, al-Qur'an dan Terjemahnya, h. 83.
} 


\section{BUSTANUL FUQAHA: \\ JURNAL BIDANG HUKUM ISLAM \\ Vol. 2 No. 3 (2021): Hal. 363-379 \\ EISSN: 2723-6021 \\ Website: https://journal.stiba.ac.id}

pada keduanya Allah swt. memperkembangbiakkan laki-laki dan perempuan yang banyak. Dan bertakwalah kepada Allah swt. yang dengan (mempergunakan) namaNya kamu saling meminta satu sama lain, dan (peliharalah) hubungan silaturahmi. Sesungguhnya Allah swt. selalu menjaga dan mengawasi kamu ${ }^{20}$.

Ayat ini menegaskan suatu perintah kepada umat manusia untuk menjaga hubungan kekeluargaan atau pertalian darah, dan keluarga yang mempunyai hubungan kekeluargaan tersebut haruslah diberikan kasih sayang dan juga harus diberikan santunan. ${ }^{21}$

d) Ayat Al-Qur'an yang menjelaskan secara definitif tentang ketentuan bagian ahli waris yang disebut dengan al-furüd al-muqaddarah atau bagian yang telah ditentukan, dan bagian sisa ('așabah), serta orang-orang yang tidak termasuk ahli waris, disebutkan dalam Qs. An-Nisā/4:11,

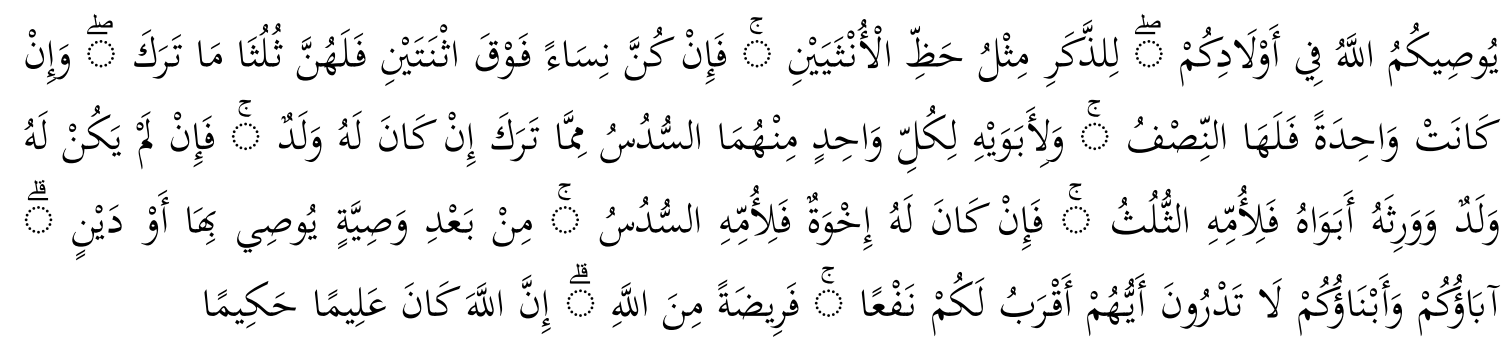

Terjemahnya:

Allah mensyariatkan bagimu tentang (pembagian pusaka untuk) anak-anakmu.

Yaitu: bahagian seorang anak lelaki sama dengan bahagian dua orang anak perempuan; dan jika anak itu semuanya perempuan lebih dari dua, maka bagi mereka dua pertiga dari harta yang ditinggalkan; jika anak perempuan itu seorang saja, maka ia memperoleh separo harta. Dan untuk dua orang ibu-bapak, bagi masing-masingnya seperenam dari harta yang ditinggalkan, jika yang meninggal itu mempunyai anak; jika orang yang meninggal tidak mempunyai anak dan ia diwarisi oleh ibu-bapaknya (saja), maka ibunya mendapat sepertiga; jika yang meninggal itu mempunyai beberapa saudara, maka ibunya mendapat seperenam. (Pembagian-pembagian tersebut di atas) sesudah dipenuhi wasiat yang ia buat atau (dan) sesudah dibayar utangnya. (Tentang) orang tuamu dan anak-anakmu, kamu tidak mengetahui siapa di antara mereka yang lebih dekat (banyak) manfaatnya bagimu. Ini adalah ketetapan dari Allah. Sesungguhnya Allah Maha Mengetahui lagi Maha Bijaksana ${ }^{22}$.

2) Sunah

Dasar hukum kewarisan yang kedua, yaitu dasar hukum yang terdapat dalam hadis Nabi Muhammad saw. Dari sekian banyak hadis Nabi saw. yang menjadi landasan hukum kewarisan Islam, di antaranya sebagai berikut:

\footnotetext{
${ }^{20}$ Kementerian Agama Republik Indonesia, Al-Qur'an dan Terjemahnya, h. 81.

${ }^{21}$ Suhrawardi K Lubis dan Komis Simanjuntak, Hukum Waris Islam, (Cet III: Jakarta: Sinar Grafika, 2001)h. 28.

${ }^{22}$ Kementerian Agama R.I., Al-Qur'an dan Terjemahnya, (Cet. I, Jakarta: Sahifa, 2014), h. 78.
} 
a) Menyangkut pembagian harta warisan kepada ahli waris berdasarkan bagian-bagian ahli waris yang telah ditentukan dalam syariat. Sebagaimana dalam riwayat dari Ibnu 'Abbas ra. dari Nabi saw. bersabda: Berikanlah faraid (bagian bagian yang ditentukan) itu kepada yang berhak dan selebihnya berikanlah untuk laki-laki dari keturunan laki-laki yang dekat. (HR. al-Bukhārī) ${ }^{23}$. Dengan demikian, penjelasan dari hadis tersebut yaitu maka berikanlah warisan sesuai ketentuan yang telah ditetapkan oleh Allah swt. jika berlebih maka berikanlah untuk laki-laki dari keturunan laki-laki yang dekat.

b) Hadis tentang pembagian harta warisan kepada anak laki-laki dan suami serta ahli waris lainnya. Sebagaimana dalam riwayat dari Abu Hurairah ra. bahwasanya ia mengatakan, Rasulullah saw. menetapkan tentang janin wanita dari Bani Lahyan yang keguguran dengan ghurrah (pembayaran diyat dengan satu budak atau budak perempuan), kemudian wanita yang beliau putuskan membayar ghurrah meninggal, maka Rasulullah saw memutuskan bahwa warisannya untuk anak laki-lakinya dan suaminya, sedang diyatnya bagi 'aṣabahnya. (HR. al- Bukhārī) ${ }^{24}$.

\section{3) Al-Ijmā'}

Al-Ijmā' yaitu kesepakatan kaum muslimin menerima ketentuan hukum-hukum warisan yang terdapat di dalam al-Qur'an dan sunah, sebagai ketentuan hukum yang harus dilaksanakan dalam upaya mewujudkan keadilan dalam masyarakat. Sehingga, tidak ada alasan untuk menolaknya karena ketentuan tersebut telah diterima secara mufakat. Adapun yang dimaksud Ijma' dalam hukum kewarisan adalah kesepakatan para ulama atau sahabat setelah Rasulullah saw. meninggal mengenai ketentuan warisan yang terdapat dalam al-Qur'an dan sunah. Sebagai contoh dari Ijma' adalah kata Ummahāt (para ibu) dalam Qs. Al-Nisā/4:23, mencakup ibu kandung dan nenek, sedangkan kata Banāt (anak-anak wanita) mencakup cucu perempuan dan anak perempuan ${ }^{25}$.

4) Al- Ijtihād

Ijtihad yaitu pemikiran para sahabat atau ulama yang memiliki cukup syarat dan kriteria sebagai mujtahid untuk menjawab persoalan-persoalan yang mengemuka, termasuk di dalamnya tentang pembagian harta warisan yang belum atau tidak disepakati. Adapun yang dimaksud adalah ijtihad dalam menerapkan hukum, bukan untuk mengubah pamahaman atau ketentuan yang ada ${ }^{26}$. Penggunaan akal dalam berijtihad dalam menemukan dan merumuskan suatu hukum Allah swt. tidak akan menghasilkan kebenaran yang mutlak, karena kebenaran yang mutlak ditemukan secara langsung pasti dan dijelaskan oleh Allah swt.

\section{Rukun dan Syarat Kewarisan Islam}

1) Rukun Kewarisan Islam

${ }^{23}$ Muḥammad bin Ismā’̄il bin Ibrahīm bin Al-Mugīrah bin Al-Bardiżbah Al-Bukhārī, Śậ̄ḥ AlBukhārī, Juz 8, h. 269. Hadis no. 6238. (Cet I:t,p: Beirut)

${ }^{24}$ Muḥammad bin Ismā'îl bin Ibrahīm bin Al-Mugīrah bin Al-Bardiżbah Al-Bukhārī, Śah̄ịh AlBukhārī, Juz 8, h. 272. Hadis no. 6243

${ }^{25}$ Ahmad Rofiq, Fiqh Mawaris, h. 27.

${ }^{26}$ Ahmad Rofiq, Fiqh Mawaris, h. 27. 
Rukun dalam kewarisan merupakan bagian dari sesuatu yang tidak dapat dibagi kecuali adanya rukun tersebut. Seperti halnya rukuk dalam salat merupakan bagian rukun salat, bila tidak rukuk, maka salatnya batal ${ }^{27}$. Di dalam hukum kewarisan terdapat beberapa rukun yang bisa menyebabkan terjadinya pembagian harta warisan antara lain sebagai berikut:

a) Al-Muwarriș/Pewaris

Muwarriș adalah orang yang meninggal dunia dan meninggalkan harta warisan ${ }^{28}$. Di dalam Kamus Besar Bahasa Indonesia (KBBI) disebut dengan "Pewaris", sedangkan dalam kitab fikih disebut dengan muwarriș. Bagi muwarriș berlaku ketentuan bahwa harta yang ditinggalkan olehnya secara sempurna, dan ia benar-benar telah meninggal dunia baik menurut kenyataan maupun menurut hukum. Kematian para muwarris menurut para ulama fikih dibedakan menjadi tiga macam, yakni ${ }^{29}$ :

(1) Mati haqīq $\bar{l}$ yakni kematian seseorang yang semula nyawa itu sudah berwujud padanya. Kematian ini dapat disaksikan oleh panca indera dan tanpa harus dibuktikan dengan alat pembuktian.

(2) Mati hukmi adalah kematian seseorang yang secara hukum ditetapkan melalui keputusan hakim dinyatakan telah meninggal dunia. Salah satu kematian yang terjadi oleh sebab adanya hakim, baik pada hakikatnya seseorang benar-benar hidup maupun atau kemungkinan antara hidup dan mati.

(3) Mati taqdīri, yaitu perkiraan bahwa seorang telah meninggal dunia. Misalnya seseorang yang diketahui ikut berperang ke medan perang atau tujuan lain yang secara lahiriah diduga dapat mengancam keselamatan dirinya. Setelah beberapa tahun, ternyata tidak diketahui kabar beritanya dan diduga secara kuat bahwa orang tersebut telah meninggal dunia, maka ia dapat dinyatakan telah meninggal.

b) Wāriș/ahli waris

Wāriș adalah seseorang yang masih hidup setelah kematian pewaris yang akan mewarisi harta peninggalan muwarris ${ }^{30}$. Pengertian ahli waris di sini adalah orang yang mendapat harta waris karena haknya yang dinyatakan mempunyai hubungan kekerabatan baik karena hubungan darah atau hubungan sebab perkawinan. Demikian pula yang berhak menerima harta waris yang mungkin saja di luar ahli waris. Adapun ahli waris itu ada yang ditetapkan secara khusus dan langsung oleh Allah swt. dalam al-Qur'an dan oleh Nabi saw. dalam hadisnya, adapula yang ditemukan melalui ijtihad denagn meluaskan lafaz yang terdapat dalam nas hukum dan adapula yang dipahami dari petunjuk umum dari al-Qur' an atau hadis Nabi Muhammad saw ${ }^{31}$.

c) Tarikah (Harta Peninggalan)

${ }^{27}$ Ṣalih bin Fauzān bin 'Abdullah al-Fauzān, Al-Tahqīqātu al-Marḍiyyah fì al-Mabāhis alFardiyyah, h. 30-31.

${ }^{28}$ Șālih bin Fauzān bin 'Abdullah al-Fauzān, Al-Tahqīqātu al-Mardiyyah fì al-Mabāhis alFardiyyah, h.31.

${ }^{29}$ Șālih bin Fauzān bin 'Abdullah al-Fauzān, Al-Tahqūqātu al-Mardiyyah fì al-Mabāhis alFardiyyah, h. 36.

${ }^{30}$ Șālih bin Fauzān bin 'Abdullah al-Fauzān, Al-Tahqūqātu al-Mardiyyah fì al-Mabāhis̉ alFardiyyah, h. 31.

${ }^{31}$ Amir Syarifuddin, Garis-Garis Besar Fiqh (Cet.I; Bogor: Prenada Media, 2003), h. 155. 
Harta peninggalan atau haknya ahli waris yaitu ditinggalkan oleh si mati. Harta peninggalan dalam kitab fikih biasa juga disebut dengan tarikah, yaitu apa-apa yang ditinggalkan oleh orang yang meninggal dunia baik berupa harta secara mutlak. Jumhur Fuqah $\bar{a}$ ' berpendapat bahwa tarikah adalah segala sesuatu yang menjadi milik seseorang, baik harta benda atau hak-hak kebendaan yang diwarisi oleh si ahli warisnya setelah ia meninggal dunia. Pengertian harta peninggalan terdapat dalam KHI pasal 171 huruf D yang menyatakan bahwa harta peninggalan adalah harta yang ditinggalkan oleh pewaris baik berupa benda yang menjadi miliknya maupun hak-haknya ${ }^{32}$.

2) Syarat Kewarisan Islam

Syarat merupakan ketentuan yang mengharuskan ketiadaannya maka dianggap tidak ada dan ketentuan yang mengharuskan ada, maka dianggap ada atau terpenuhi dan tidak meniadakan yang sudah jelas ketetapannya ${ }^{33}$. Syarat-syarat waris dalam kewarisan itu ada tiga, yaitu ${ }^{34}$ :

a) Meninggalnya pewaris, baik secara haqīqi maupun secara hukmi ditetapkan bahwa pewaris benar-benar meninggal dunia. Sebagai contoh, orang yang hilang yang keberadaanya tidak diketahui di mana dan bagaimana keadaanya. Setelah melakukan berbagai macam upaya, melalui putusan hakim orang tersebut dinyatakan meninggal dunia, maka putusan hakim bersifat tetap dan mengikat.

b) Adanya ahli waris yang hidup, secara haqīqi pada waktu pewaris meninggal dunia. Maksudnya hak kepemilikan dari pewaris harus dipindahkan kepada ahli waris yang secara syariat yang benar-benar masih hidup, sebab orang yang sudah mati tidak memiliki hak untuk mewarisi. Hidupnya wāriș (ahli waris) mutlak harus dipenuhi. Seorang ahli waris hanya akan mewarisi jika dia masih hidup ketika pewaris meninggal dunia. Masalah yang biasanya muncul berkaitan dengan hal ini antara lain mafqūd, anak dalam kandungan, dan mati berbarengan.

c) Seluruh ahli waris diketahui secara pasti, termasuk jumlah bagian masing-masing. Dalam hal ini, posisi para ahli waris hendaklah diketahui secara pasti, misalnya suami, istri, kerabat, dan sebagainya. Sehingga, pembagi mengetahui dengan pasti jumlah bagian yang harus diberikan kepada masing-masing ahli waris. Sebab, dalam hukum waris, perbedaan jauh-dekatnya kekerabatan akan membedakan jumlah yang diterima, karena tidak cukup hanya mengatakan bahwa seseorang adalah saudara si pewaris. Akan tetapi, harus dinyatakan apakah ia sebagai saudara kandung, saudara seayah, atau saudara seibu.

\section{Sebab-Sebab Mendapat Warisan dan Penghalangnya}

1) Sebab-sebab Mendapat Kewarisan

Kesepakatan para ulama ada 3 (tiga) sebab seseorang bisa mendapatkan bagian warisan dari seorang yang telah meninggal. Ketiga sebab itu adalah pernikahan yang

\footnotetext{
${ }^{32}$ Tim Redaksi Nuansa Aulia, Kompilasi Hukum Islam, h. 50.

${ }^{33}$ Șālih bin Fauzān bin 'Abdullah al-Fauzān, Al-Tahqīqātu al-Marḍiyyah fì al-Mabāhis̀ alFardiyyah, h. 35.

${ }^{34}$ Șālih bin Fauzān bin 'Abdullah al-Fauzān, Al-Tahqūqātu al-Marḍiyyah fì al-Mabāhis̉ alFardiyyah, h. 35.
} 


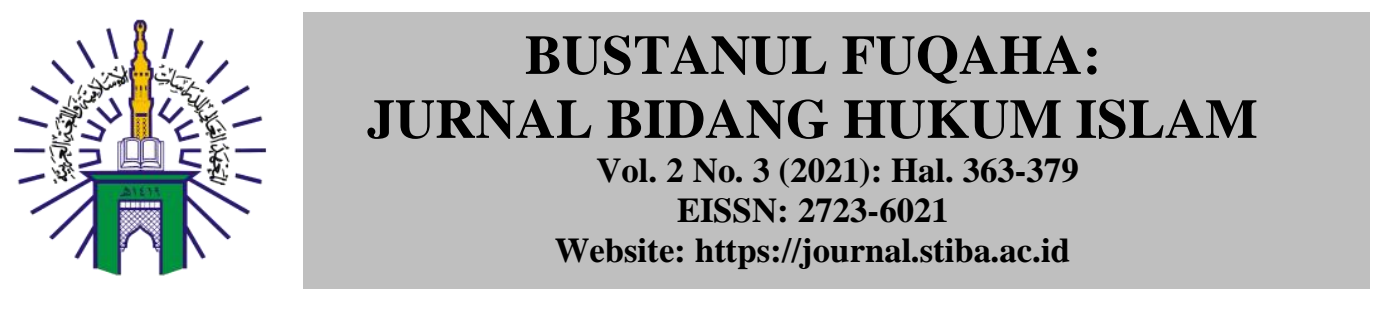

\section{BUSTANUL FUQAHA}

Jurnal Bidang Hukum Islam

sah, wala' (kekerabatan karena memerdekakan budak), dan hubungan nasab sebagai berikut ${ }^{35}$ :

a) Pernikahan yang terjadi dengan akad yang sah. Meskipun belum terjadi persetubuhan di antara pasangan suami istri namun dengan adanya ikatan perkawinan yang sah maka keduanya bisa saling mewarisi satu sama lain. Bila suami meninggal, istri bisa mewarisi harta yang ditinggalkannya, dan bila istri yang meninggal maka suami bisa mewarisi harta peninggalannya. Termasuk bisa saling mewarisi karena hubungan pernikahan adalah bila pasangan suami istri bercerai dengan talak raj' $i$ kemudian salah satunya meninggal dunia maka pasangannya bisa mewarisi selama masih dalam masa idah talak raj'i tersebut. Sedangkan pasangan suami istri yang menikah dengan pernikahan yang fasid (rusak), seperti pernikahan tanpa adanya wali atau dua orang saksi, keduanya tidak bisa saling mewarisi. Demikian pula pasangan suami istri yang menikah dengan nikah mut'ah.

b) Al-Wala' adalah hubungan kewarisan akibat seseorang memerdekakan hamba sahaya, atau melalui perjanjian tolong menolong ${ }^{36}$. Adapun bagian orang yang memerdekakan hamba sahaya adalah seperenam dari harta peninggalan. Jika kemudian ada pertanyaan, apakah sekarang masih ada hamba sahaya, maka jawabannya adalah bahwa terhapusnya perbudakan merupakan salah satu keberhasilan misi Islam.

c) Nasab atau kekerabatan. Orang yang bisa mendapatkan warisan dengan sebab nasab atau kekerabatan adalah kedua orang tua dan orang-orang yang merupakan turunan keduanya seperti saudara laki-laki atau perempuan serta anak-anak dari para saudara tersebut baik sekandung maupun seayah. Termasuk juga anak-anak dan orang-orang turunannya, seperti anak laki-laki dan perempuan serta anak dari anak laki-laki (cucu dari anak laki-laki) baik laki-laki maupun perempuan.

2) Penghalang Kewarisan

Di dalam hukum Islam ada beberapa hal yang menjadi penghalang bagi seseorang untuk menerima warisan. Dengan adanya penghalang tersebut maka seseorang yang semestinya bisa menerima harta warisan yang ditinggalkan oleh kerabatnya menjadi tidak bisa menerimanya. Para ulama menetapkan ada 3 (tiga) hal yang menjadikan seseorang terhalang untuk mendapatkan harta warisan. Ketiga hal tersebut yaitu:

a) Status budak. Orang yang berstatus budak, apa pun jenisnya tidak bisa menerima harta warisan karena bila seorang budak menerima warisan maka harta warisan yang ia terima itu menjadi milik tuannya, padahal sang tuan adalah bukan siapa-siapanya (ajnabi $)$ orang yang meninggal yang diwarisi hartanya. Seorang budak juga tidak bisa diwarisi hartanya karena sesungguhnya ia tidak memiliki apa-apa. Bagi seorang budak, diri dan apapun yang ada bersamanya adalah milik tuannya. Mayoritas ulama sepakat seorang budak terhalang untuk menerima warisan karena tidak cakap melakukan perbuatan hukum.

35 Șālih bin Fauzān bin 'Abdullah al-Fauzān, Al-Tahqīqātu al-Mardiyyah fì al-Mabāhis̉ alFardiyyah, h. 38.

${ }^{36}$ Șālih bin Fauzān bin 'Abdullah al-Fauzān, Al-Tahqīqātu al-Marḍiyyah fì al-Mabāhis alFardiyyah, h. 42. 
b) Membunuh. Orang yang membunuh tidak bisa mewarisi harta peninggalan dari orang yang dibunuhnya, baik ia membunuhnya secara sengaja atau karena suatu kesalahan. Hal ini dikarenakan membunuh sama saja dengan memutus hubungan kekerabatan, sedangkan hubungan kekerabatan merupakan salah satu sebab seseorang bisa menerima warisan. Imam Abu Dawud meriwayatkan sebuah hadis dari kakeknya Amr bin Syu'aib, bahwa Rasulullah saw. bersabda, yang berbunyi: "Pembunuh tidak mendapatkan apa-apa, jika ia tidak mempunyai ahli waris, maka warisannya jatuh kepada orang yang paling dekat dengannya, dan bagi pembunuh tidak mendapatkan warisan sedikitpun." (HR. Abū Dāud) ${ }^{37}$

c) Perbedaan agama antara Islam dan kufur. Orang yang beragama non-Islam tidak bisa mendapatkan harta warisan dari keluarganya yang meninggal beragama Islam. Juga sebaliknya seorang muslim tidak bisa menerima warisan dari harta peninggalan keluarganya yang meninggal beragama non-Islam. Hal ini berdasarkan hadis riwayat Imam Bukhari yang menyatakan, Dari Zaid ra. Sesungguhnya Nabi saw. bersabda: "Seorang Muslim tidak bisa mewarisi seorang kafir, dan seorang kafir tidak bisa mewarisi seorang Muslim." (HR. al-Bukhārī) $)^{38}$.

\section{Pembagian Warisan Sebelum Pewaris Meninggal Dunia dalam Tinjauan Hukum Islam}

Allah swt. telah menjelaskan di dalam al-Qur'an ihwal pokok-pokok kewarisan dan hak-hak ahli waris menurut bagian yang tertentu, walaupun ungkapan dan gaya bahasa yang digunakan untuk menjelaskan hukumnya adalah dalam bentuk berita, jika ditinjau dari segi ketentuan yang bersifat normatif, maka keharusan ahli waris atau orang yang ikut menyelesaikan pembagian warisan untuk mengikuti norma yang telah ditetapkan Allah swt.

Sebelum langsung membagikan harta warisan kepada ahli waris, maka masih ada suatu tindakan sukarela dari pihak yang memiliki penuh harta tersebut, yaitu memberi ala kadarnya kepada pihak-pihak yang tidak berhak atas harta itu secara kewarisan, apabila masih ada harta warisan yang tersisa. Tindakan yang bersifat sukarela itu dijelaskan Allah swt. Dalam Qs. An-Nisa/4:8,

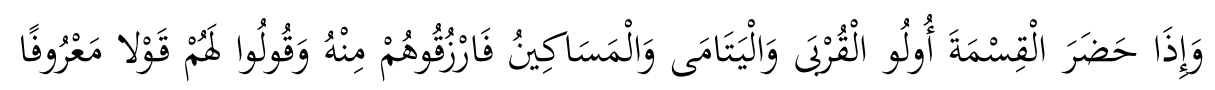

Terjemahnya:

Dan apabila sewaktu pembagian itu hadir kerabat, anak yatim dan orang miskin, maka berilah mereka dari harta itu (sekadarnya) dan ucapkanlah kepada mereka perkataan yang baik ${ }^{39}$.

Dalam ayat tersebut disebutkan bahwa yang akan menerima pemberian harta sukarela adalah kerabat, anak yatim dan orang miskin. Namun, tentang jumlahnya tidak

${ }^{37}$ Sulaiman bin al-Asy'at al-Azdī Abū Dāud, Sunan Abī Dāūd, Juz 6 (Cet. I; Beirūt:Dār al-risālah al-‘ālamiyyah, 2009 M/1430 H) h. 621. Hadis no. 4564.

${ }^{38}$ Muḥammad bin Ismā’īl bin Ibrahīm bin Al-Mugīrah bin Al-Bardiżbah Al-Bukhārī, Śahịh AlBukhārī, Juz 8, h. 279. Hadis no. 6267.

${ }^{39}$ Kementerian Agama Republik Indonesia, Al-Qur'an dan Terjemahnya, h. 78. 
disebutkan. Tentunya, hal tersebut didasarkan kepada ukuran kepatutan yang tidak akan merugikan ahli waris. Bila diperhatikan maksud dari Qs. al-Nisā/4:8, maka sangat jelas terlihat kebijaksanaan yang diberikan Allah swt. dalam sistem kewarisan Islam.

Ada beberapa pendapat tentang pembagian harta warisan sebelum pewaris meninggal dunia, yaitu: menurut Komplikasi Hukum Islam (KHI) di Indonesia membagikan harta warisan sebelum pewaris meninggal dilaksanakan setelah menunaikan seluruh kewajiban ahli waris dan sangat penting untuk memperhatikan keadilan. Betapa pun juga ketentuan warisan di dalam al-Qur'an tetap menjadi rujukan yang utama. Hal ini dikarenakan baik bagi pewaris yang akan menghadap kepada Sang Khaliq juga tidak terbebani karena persoalan kebendaan, dan ahli warisnya juga dapat menerima kenyataan dari bagian yang seharusnya diterima dengan penuh keikhlasan ${ }^{40}$.

Pendapat pertama yaitu dari Muḥammad bin Șālih al-Us̉aimin, mengemukakan bahwa:

"Sikap yang terbaik adalah dengan membiarkan harta tidak dibagikan sebelum pewaris meninggal karena tidak ada yang tahu apa yang akan terjadi dalam kehidupan kita. Untuk itu, jangan catatkan harta Anda untuk siapapun, sebab jika Allah swt. menakdirkan Anda meninggal, maka para ahli waris Anda akan mewarisi harta Anda sesuai dengan ketentuan Allah swt. Lalu, bagaimana mungkin Anda mencatatkan atas nama mereka, sementara mereka itu para ahli waris Anda, dan Anda pun tentu tidak tahu, boleh jadi mereka meninggal sebelum Anda, sehingga malah Anda yang mewarisi harta mereka. Yang jelas, kami sarankan agar Anda tetap memegang harta Anda, tidak mencatatkannya untuk seseorang. Biarkan ditangan anda, dan anda pergunakan sesuka anda dalam batas-batas yang dibolehkan syari'at. Jika salah seorang dari anda meninggal, maka yang lainnya otomatis akan mewarisinya sesuai dengan yang telah ditetapkan Allah swt. Dan rasulNya." ${ }^{41}$

Pendapat kedua dari Ibnu Hajar al-Haitami, mengemukakan bahwa:

"Sebelum membagikan hartanya kepada ahli warisnya, ada dua kemungkinan skema yang berlaku yaitu hibah atau warisan. Jika yang dimaksudkan adalah hibah maka tidak mengapa, namun jika itu adalah harta warisan, maka harus mengikuti aturan pembagian warisan yang telah ditetapkan oleh Allah swt. Jika orang tua membagikan hartanya kepada anaknya dalam bentuk anak tidak memiliki hak milik secara syar'i (menunggu orang tua meninggal) maka pembagian warisan sebelum pewaris meninggal adalah batal. Sehingga ketika orang tua meninggal dunia, maka semua yang dimiliki orang tua menjadi warisan bagi anak-anaknya dimana anak laki-laki mendapat jatah dua kali anak perempuan." ${ }^{42}$

Jadi, dari beberapa pendapat di atas dapat disimpulkan bahwa pembagian warisan dalam Islam harus sesuai dengan aturan yang telah ditetapkan oleh Allah swt. Hal ini dikarenakan dengan sistem kewarisan Islam maka semua sistem kewarisan di luar Islam dapat diakomodasi dan disesuaikan ke dalam sistem Islam. Terhadap waktu pembagian warisan menurut al-Qur'an tidak diatur secara jelas, namun secara tersirat Islam mengajarkan untuk menyegerakan dalam melakukan kebaikan

Ketentuan waris Islam menganjurkan pembagian warisan harus menyegerakan untuk dilaksanakan karena dikhawatirkan akan terjadi konflik internal dalam keluarga atau harta warisan yang nilai atau jumlahnya tidak akan sama bila tidak diselesaikan segera. Karena

${ }^{40}$ Ahmad Rafiq, Fiqh Mawaris, h. 201-202.

${ }^{41}$ Khalid al-Juraisi, al-fatāwā al-Syar'iyyah fì al-Masāil al- 'ashriyyah min fatāwā 'Ulamā' alBalad al-Harām, Juz 3 (Cet. I; Riyaḍ: Mu’asasah al-Juraisi, 1999 M /1420 H) h. 541.

${ }^{42}$ Aḥmad Bin 'Abd al-Halīm Bin 'Abd al-Salām Ibnu Taimiyyah, Al-fatāwa al-Kubrā, juz 4 (Cet. I; Bairūt: Dār al-Kutub al-‘ilmiyyah, 1987 M/1408 H), h. 400. 
harta peninggalan biasanya tidak hanya berupa uang namun bisa berupa bangunan, tanah atau bangunan yang memiliki nilai. Hukum waris Islam memandang bahwa terjadinya pembagian warisan hanya semata-mata disebabkan adanya kematian. Dengan kata lain, harta warisan seseorang tidak beralih seandainya dia masih hidup.

\section{Analisis Tinjauan Hukum Islam Terhadap Pembagian Warisan Sebelum Pewaris Meniggal Dunia pada Kasus yang Terjadi di Masyarakat Desa Gentungang}

Berdasarkan hasil penelitian melalui wawancara dengan beberapa informan di Desa Gentungang, terungkap bahwa pembagian warisan sebelum pewaris meninggal dunia yang dilakukan oleh masyarakat Gentungang tersebut bukan termasuk warisan melainkan sebagai hibah dari orang tua sebagai pewaris kepada anak-anaknya. Pembagian dan peralihan harta dalam hukum kewarisan Islam hanya dapat dilakukan setelah seseorang meninggal dunia. Peralihan harta yang terjadi sebelum seseorang meninggal dunia tidak dikatakan sebagai harta warisan. Pemberian harta yang dilakukan ketika masih hidup dapat disebut sebagai hadiah, wasiat, atau hibah. Sebab banyak hal yang harus diselesaikan ketika pewaris meninggal dunia, seperti utang pewaris, wasiat dan lain-lain. Sehingga, apabila pembagian harta warisan dilakukan ketika pewaris masih hidup akan dikhawatirkan justru menimbulkan perselisihan atau bahkan permusuhan di antara ahli waris setelah pewaris meninggal. Hal ini dikarenakan beberapa masalah yang mungkin ditinggalkan oleh si pewaris setelah meninggalnya, misalnya dalam hal pelunasan utangpiutang. Dalam hukum Islam, kewarisan terjadi apabila adanya kematian, sedangkan dalam penerapan sebagian masyarakat Gentungang, terlihat tidak sesuai dengan proses kewarisan menurut hukum Islam meskipun mereka sudah mengetahui proses tersebut.

Berdasarkan hasil penelitian ini, terlihat adanya percampuran hukum kewarisan yang dilakukan, yaitu memadukan kebiasaan masyarakat Gentungang yang membagikan harta warisan sebelum pewaris meninggal dunia dengan hukum waris Islam, termasuk di antaranya mengenai porsi yang diterima oleh ahli waris, sedangkan waktu pelaksanaan penyelesaian pembagian ketika pewaris (orang tua) masih hidup bukanlah digolongkan pembagian kewarisan dalam Islam. Pandangan hukum Islam bahwa pembagian harta warisan dapat dilaksanakan sebelum terjadinya kematian pada diri pewaris, apabila ada kekhawatiran akan terjadi cekcok dan atau perselisihan di antara para ahli waris yang akan menimbulkan kemudaratan.

Praktik pembagian harta warisan sebelum pewaris meninggal dunia terdapat beberapa kelemahan dan kekurangan, di antaranya adalah tidak terciptanya keadilan yang merata disebabkan tidak mengambil ketentuan pembagian harta warisan berdasarkan al-Qur'an dan hadis. Selain itu, persengketaan dalam keluarga kerapkali terjadi karena masalah warisan yang tidak dapat terhindarkan. Sehingga, dapat menimbulkan fitnah, karena salah satu timbulnya fitnah disebabkan oleh pembagian harta warisan yang tidak benar.

\section{KESIMPULAN}

Berdasarkan pengkajian analisis tinjauan hukum Islam terhadap praktik pembagian warisan sebelum pewaris meninggal dunia yang terjadi pada masyarakat Desa Gentungang Kecamatan Bajeng Barat Kabupaten Gowa, maka dapat di simpulkan bahwa: 
1. Implementasi pembagian harta warisan sebelum pewaris meninggal dunia kepada ahli waris yang dilakukan oleh masyarakat Gentungang adalah berdasarkan waktu pembagian harta warisan, dasar hukum pembagian harta warisan, alasan pemberian harta warisan sebelum pewaris meninggal dunia, jenis harta yang dibagi, proses pelaksanaan pembagian harta warisan, dan tanggapan ahli waris terhadap pembagian harta warisan sebelum pewaris meninggal dunia.

2. Tinjauan hukum Islam terhadap pelaksanaan pembagian harta warisan yang dilakukan sebelum pewaris meninggal dunia pada masyarakat Gentungang adalah hibah. Status kepemilikan harta yang diberikan pewaris semasa hidupnya sudah menjadi milik mutlak ahli waris dan tidak dapat dikembalikan lagi kepada pewaris.

\section{DAFTAR PUSTAKA}

Abu Dāud, Sulaiman bin al-Asy'at al-Azdī. Sunan Abī Dā̄ùd. Juz 4. Cet. I; Beirūt:Dār alrisālah al-'ālamiyyah, $2009 \mathrm{M} / 1430 \mathrm{H}$.

Al-Bukhārī, Muḥammad bin Ismā’̄̄l bin Ibrahīm bin Al-Mugīrah bin Al-Bardiżbah. Śậ̄̄h $A l$-Bukhārī. Juz 8 Cet. I; t.p.: Beirūt.

Al-Fauzān, Shālih bin Fauzān bin Abdullah. Al-Tahqīqātu al-Marḍiyyah fì al-Mabāhis̀ al-Fardiyyah. Cet. IV; Riyadh: Maktabah Ma'arif, 1419 H/1999 M.

Al-Juraisi, Khālid. al-fatāwā al-Syar'iyyah fì al-Masāil al-'ashriyyah min fatāwā 'Ulamā' al-Balad al-Harām. Juz 3. Cet. I; Riyaḍ: Mu'asasah al-Juraisi, 1999 $\mathrm{M} / 1420 \mathrm{H}$.

Aulia, Nuansa. Kompilasi Hukum Islam Bandung: CV Nuansa Aulia, 2017.

Ibn Katsir, Ismail bin Khatīb Abī Hafsh Umar. Tafsīru al-Qur'an al- 'Azīm. Juz I Cet. I; Bairūt: Dār al-Mufīd, 1983 M/1403 H.

Ibnu Taimiyyah, Aḥmad Bin 'Abd al-Halīm Bin 'Abd al-Salām. Al-fatāwa al-Kubrāa juz 4. Cet. I; Bairūt: Dār al-Kutub al-'ilmiyyah, 1987 M/1408 H.

Jainuddin, Jainuddin. "Pembagian Harta Warisan; Telaah Pembagian Warisan oleh Pewaris Kepada Ahli Waris Sebelum Pewaris Meninggal pada Masyarakat Bima." SANGAJI: Jurnal Pemikiran Syariah dan Hukum 4.2 (2020): 298-313.

KBBI Daring. "Waris." https://kbbi.kemdikbud.go.id/entri/waris, diakses tanggal 30 September 2021.

K Lubis, Suhrawardi dan Komis Simanjuntak. Hukum Waris Islam. Cet. III; Jakarta: Sinar Grafika, 2001.

Kementerian Agama Republik Indonesia. Al-Qur'an dan Terjemahnya. Cet. I; Jakarta: Sahifa, 2014.

Megawati. "Sistem Pelaksanaan Pembagian Harta Warisan Pada Masyarakat Islam di Desa Parappe Kecamatan Campalagian Kabupaten Polewali Mandar Sulawesi Barat”. Skripsi. Makassar: Fakultas Syari'ah dan Hukum UIN Alauddin Makassar 2016.

Nurjannah. "Pembagian Harta Sebelum Orang Tua Meninggal Dunia Pada Masyarakat Adat Bulukumba Ditinjau Dari Hukum Islam (Studi Kasus Di Kelurahan Caile Kecamatan Ujung Bulu Kabupaten Bulukumba". Skripsi. Makassar: Fakultas Syari'ah dan Hukum UIN Alauddin Makassar 2012. 


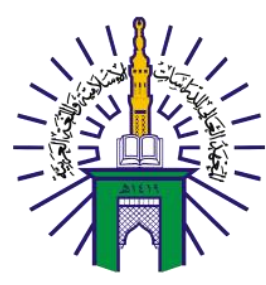

\section{BUSTANUL FUQAHA: \\ JURNAL BIDANG HUKUM ISLAM \\ Vol. 2 No. 3 (2021): Hal. 363-379 \\ EISSN: 2723-6021 \\ Website: https://journal.stiba.ac.id}

Poespasari, Ellyne Dwi. Hukum Waris Adat Di Indonesia. Cet. I; Jakarta: Prenada Media Group, 2018.

Rofiq, Ahmad. Fiqh Mawaris. Cet. IV; Jakarta: RajaGrafindo Persada, 2002.

Rukiah, Rukiah, and Herman Herman. "Penyelesaian Sengketa dalam Kewarisan Adat dalam Perspektif Hukum Islam." DIKTUM: Jurnal Syariah dan Hukum 9.2 (2011): 113-131.

Syarifuddin, Amir. Garis-Garis Besar Fiqh. Cet. I; Jakarta: Prenada Media, 2003.

Syarifuddin, Amir. Hukum Kewarisan Islam. Cet. I; Jakarta: Prenada Media, 2004. 